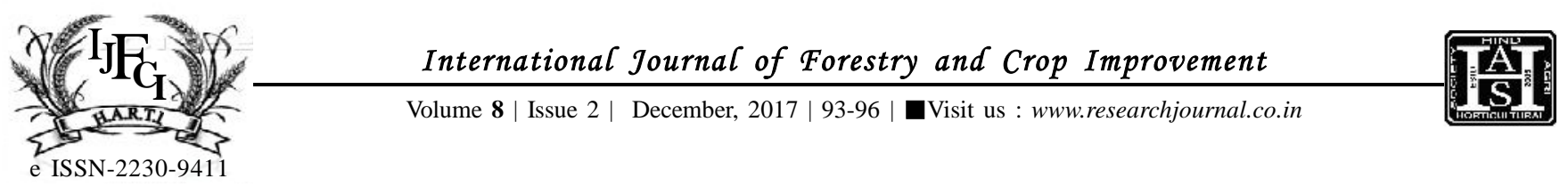

RESEARCH ARTICLE

DOI: $10.15740 / \mathrm{HAS} / \mathrm{IJFCI} / 8.2 / 93-96$

\title{
Effect of needle punch technique on the properties of MDF board from bamboo (Dendrocalamus strictus)
}

\author{
KaPIL SiHAG, ANILNEGI, D.P. KHALIAND ANIL KuMAR
}

\begin{abstract}
Bamboo is as a raw material found in whole over India. A number of production techniques can be used to improve the properties of MDF; particularly the tensile strength perpendicular to grain (internal bond). One of the new techniques is needle punch. Where-in the wooden frame with needles is used to punch the fibre mattress before making a board. Effect of needle punch technique on physical and mechanical properties of MDF board was evaluated. Boards were prepared from bamboo with $6 \%, 8 \%$ and $10 \%$ phenol formaldehyde resin using needle punch technique (two time punch) after the mat formation at three different pressure i.e., $14 \mathrm{~kg} / \mathrm{cm}^{2}, 17.5 \mathrm{~kg} / \mathrm{cm}^{2}$ and $21 \mathrm{~kg} / \mathrm{cm}^{2}$, respectively, for 15 minute hot pressing. The physical and mechanical properties of MDF board were evaluated as per IS specification 12406:2003.An increase trend in the internal bond strength of MDF board with the increase in needle punching during mat formation as well as resin content and pressure was observed. The results indicate that suitable MDF boards can be prepared using needle punch technique (two time punch) with $10 \%$ resin content at $21 \mathrm{~kg} / \mathrm{cm}^{2}$ specific pressure which meets most of the other physical and mechanical properties as per IS: 12406:2003. Some of the physical properties of board like water absorption and general swelling were higher than the Indian Standard requirements which can be controlled by suitable treatment.
\end{abstract}

KEY WORDS : MDF Board, Dendrocalamus strictus, Bamboo fibre, Phenol formaldehyde

How TO CITE THIS ARTICLE : Sihag, Kapil, Negi, Anil, Khali, D.P. and Kumar, Anil (2017). Effect of needle punch technique on the properties of MDF board from bamboo (Dendrocalamus strictus). Internat. J. Forestry \& Crop Improv., 8 (2) : 93-96, DOI: 10.15740/HAS/ IJFCI/8.2/93-96.

ARTICLE CHRONICAL : Received : 08.06.2017; Revised : 27.10.2017; Accepted : 08.11.2017

Address of the Correspondence : KAPIL SIHAG, Forest Research Institute, DEHRADUN (UTTARAKHAND) INDIA

Email: kapilsihag@gmail.com

Address of the Coopted Authors : ANIL NEGI, Directorate of Education, ICFRE, DEHRADUN (UTTARAKHAND) INDIA

Email: badalanil253@gmail.com

D.P. KHALI, Forest Research Institute, DEHRADUN (UTTARAKHAND) INDIA

ANIL KUMAR, Indian Agriculture Research Institute, NEW DELHI (INDIA) 